OPEN ACCESS

Edited by:

Julie A. Chowen,

Hospital Infantil Universitario Niño

Jesús, Spain

Reviewed by:

Laura Maria Frago,

Autonomous University of Madrid,

Spain

Marie-Stéphanie Clerget-Froidevaux, Muséum National d'Histoire Naturelle,

France

*Correspondence: Yacir Benomar yacir.benomar@u-psud.fr

Specialty section: This article was submitted to Neuroendocrine Science, a section of the journa Frontiers in Endocrinology

Received: 31 July 2018 Accepted: 15 February 2019 Published: 08 March 2019

Citation: Benomar Y and Taouis M (2019) Molecular Mechanisms Underlying

Obesity-Induced Hypothalamic Inflammation and Insulin Resistance: Pivotal Role of Resistin/TLR4 Pathways. Front. Endocrinol. 10:140. doi: 10.3389/fendo.2019.00140

\section{Molecular Mechanisms Underlying Obesity-Induced Hypothalamic Inflammation and Insulin Resistance: Pivotal Role of Resistin/TLR4 Pathways}

\author{
Yacir Benomar* and Mohammed Taouis \\ Paris-Saclay Institute of Neuroscience, NeuroPSI-UMR 9197, Molecular Neuroendocrinology of Food Intake, CNRS, \\ University Paris-Sud, University Paris-Saclay, Orsay, France
}

Low-grade inflammation and insulin resistance are among the clinical features of obesity that are thought to promote the progressive onset of type 2 diabetes. However, the underlying mechanisms linking these disorders remain not fully understood. Recent reports pointed out hypothalamic inflammation as a major step in the onset of obesity-induced insulin resistance. In light of the increasing prevalence of obesity and T2D, two worldwide public health concerns, deciphering mechanisms implicated in hypothalamic inflammation constitutes a major challenge in the field of insulin-resistance/obesity. Several clinical and experimental studies have identified resistin as a key hormone linking insulin-resistance to obesity, notably through the activation of Toll Like Receptor (TLR) 4 signaling pathways. In this review, we present an overview of the molecular mechanisms underlying obesity-induced hypothalamic inflammation and insulin resistance with peculiar focus on the role of resistin/TLR4 signaling pathway.

Keywords: obesity, insulin resistance, inflammation, hypothalamus, resistin, TLR4

\section{INTRODUCTION}

Obesity is a global epidemic triggering significant morbidity and mortality rate, through mainly interactions between genetic and environmental factors, notably sedentary lifestyle and unhealthy eating habits (1-3). Obesity is directly or indirectly associated to myriad of metabolic disorders and dysfunctions including chronic low-grade inflammation and insulin resistance, which are causally related to the development and progression of type 2 diabetes (T2D) (4-6). Numerous studies have been dedicated to understand the relationship between obesity, inflammation, and insulin resistance. In rodents, the consumption of High Fat Diet (HFD) predisposes to obesity, insulin resistance, and low-grade inflammation (7-9). HFD consumption altered both leptin and insulin hypothalamic responsiveness leading to the deregulation of energy homeostasis control. Indeed, these two hormones are anorexigenic and considered as key regulators of energy homeostasis $(10,11)$. Additionally, HFD deregulates hypothalamic neuronal circuitries, known to finely adapt hypothalamic response to body energy needs, leading to body weight gain, obesity, and T2D (12-14). More recently, hypothalamic inflammation has been identified as a critical 
event initiating the onset of obesity-induced insulin resistance and inflammation $(4,7,15)$. Indeed, in contrast to HFDinduced peripheral inflammation, that is considered as a long-term consequence, hypothalamic inflammation acutely develops within few days of HFD consumption especially in the hypothalamic arcuate nucleus (ARC) in association with both insulin/leptin resistance and the upregulation of neuronal injury markers $(8,15,16)$. These data suggest that hypothalamic inflammation is a major step in the early onset of the deregulation of energy homeostasis control and insulin resistance induced by HFD. However, the mediators and the signaling pathways triggering the onset of hypothalamic inflammation and insulin resistance are not fully characterized.

In rodents, it is largely documented that obesity alters secretory adipose tissue functions mainly adipokines and pro-inflammatory cytokines secretions $(6,17)$. Among these adipokines, Resistin is described as a determinant factor in obesity-mediated inflammation and insulin resistance at both central and peripheral levels $(18,19)$. Resistin initiates its effects through the binding to TLR4 activating proinflammatory signaling pathways (19-24). Moreover, TLR4 known as a component of immune system Pattern-recognition receptors (PRRs), plays a crucial role as a trigger of metabolic inflammation and insulin resistance during obesity (2527). This review highlights molecular mechanisms underlying obesity associated hypothalamic inflammation and insulin resistance with particular focus on the role of resistin/TLR4 signaling pathway.

\section{HYPOTHALAMIC CONTROL OF ENERGY HOMEOSTASIS: KEY ROLE OF INSULIN AND LEPTIN}

The hypothalamus is the main brain area controlling feeding behavior and energy homeostasis implicating complex neuronal circuits that project toward several brain regions and brainstem $(28,29)$. Hypothalamic arcuate nucleus (ARC), ventromedial (VMH), dorsomedial (DMH), and paraventricular (PVN) nuclei are critical for energy homeostasis control. The ARC, which sits abutting the median eminence and the third ventricle in the mediobasal hypothalamus $(\mathrm{MBH})$, constitutes the key hypothalamic area that integrates peripheral hormonal and nutritional metabolic signals $(10,11,28-32)$. The ARC contains two distinct functionally antagonistic neuronal populations, the orexigenic neurons expressing the agouti-related peptide (AgRP) and the neuropeptide Y (NPY) and the anorexic neurons that include cocaine-and amphetamine-regulated transcript (CART) neurons and pro-opiomelanocortin (POMC) neurons. These ARC neurons coordinate neuronal networks involved in feeding behavior and energy expenditure control $(31,32)$.

Among the peripheral signals, the anorexigenic effect of insulin in the hypothalamus is largely documented where insulin modulates food intake and glucose homeostasis $(10,11)$. Insulin crosses blood-brain barrier (BBB) in a receptor-dependent manner to reach the hypothalamus (32). In the hypothalamus, insulin receptors (IR) are highly expressed in POMC/CART and NPY/AgRP neurons (30, 31), and central delivery of insulin increases hypothalamic expression of CART and $\alpha \mathrm{MSH}$ ( $\alpha$-melanocyte stimulating hormone), and inhibits NPY and AgRP gene expression $(33,34)$ reducing then food intake and body weight (35). Moreover, insulin regulates electrical activity of both POMC/CART and NPY/AgRP neurons through the stimulation of ATP-sensitive potassium (KATP) channel leading to membrane hyperpolarization and decreased firing of these neurons in a PI3K/Akt-dependent manner $(35,36)$. It has been also reported that insulin, through its action on hypothalamic ARC neurons, regulates hepatic glucose production $(37,38)$, glycogen synthesis (39), and fat metabolism (40, 41) via autonomous nervous system connections. Insulin action on AgRP/NPY neurons, suppresses hepatic glucose production (37), whereas it action on POMC neurons inhibits adipose-tissue lipolysis (41). Beside insulin, the adipose tissue-derived hormone Leptin also plays a critical role in the hypothalamic control of energy and glucose homeostasis. Leptin acts through its hypothalamic long isoform receptor (ObRb) to reduce food intake and increase energy expenditure by upregulating the expression of POMC and reducing the expression of NPY and AgRP (42-44). Leptin action within the hypothalamus also improved glucose utilization and insulin sensitivity in adipose tissue, muscle and liver $(45,46)$. Of note, leptin and insulin share several signaling pathways in the hypothalamus and act synergistically to modulate the central regulation of feeding and whole body energy homeostasis $(47,48)$.

\section{IMPAIRED HYPOTHALAMIC INSULIN SIGNALING IN OBESITY}

In rodents, HFD consumption is considered as an important nutritional factors predisposing to obesity-induced insulin resistance. HFD consumption alters hypothalamic insulin responsiveness deregulating energy homeostasis control (7-9). Several mechanisms have been proposed to explain the loss of hypothalamic insulin action induced by HFD. Indeed, it has been shown that the impairment of hypothalamic insulin action could result from impaired transport across the BBB reducing then hypothalamic insulin uptake (49-51). Nonetheless, the direct delivery of insulin in the brain did not reverse the obesityinduced metabolic disorders (52-55) suggesting that the defect in insulin uptake into the brain is not the only mechanism. In obese animals, hypothalamic insulin resistance might be also a consequence of impaired hypothalamic insulin signaling. This could be attributed to HFD-induced hypothalamic upregulation of suppressor of cytokine signaling (SOCS3), protein tyrosine phosphatase-1B (PTP-1B) and protein kinase C, shown to blunt hypothalamic insulin signaling pathways (56-58). It is also suggested that inhibitory interplay between leptin and insulin signaling in the hypothalamus could have a causal role in the onset and the progression of hypothalamic insulin resistance. Interestingly, numerous studies clearly reported that chronic exposure to high leptin levels, which mimics obesity-associated hyperleptinemia, promotes hypothalamic insulin resistance through the impairment of neuronal insulin signaling $(48,59$, 
60). Furthermore, obesity-induced hypothalamic inflammation may also contribute to the development of hypothalamic insulin resistance. Indeed recent studies reported that HFD activates hypothalamic inflammatory pathways, notably NF-kB and cjun N-terminal kinase (JNK), and increases proinflammatory cytokines leading to hypothalamic insulin resistance $(4,7,15)$. In humans, increasing evidence has corroborated findings obtained from rodent models that link hypothalamic inflammation and insulin resistance to the deregulation of energy homeostasis promoting obesity onset in humans $(7,16,61)$.

\section{HYPOTHALAMIC INFLAMMATION AND INSULIN RESISTANCE IN OBESITY}

Epidemiological studies in obese and insulin resistant subjects have revealed a causal link between increased pro-inflammatory markers and decreased insulin sensitivity $(7,62)$. In rodents it is now recognized that HFD-induced metabolic inflammation contributes to metabolic disorders including insulin resistance $(7,63)$. This inflammatory state occurs particularly in adipose tissue, implicating the recruitment of immune cells and the activation of resident macrophages exacerbating adipose tissue inflammation and production of proinflammatory cytokines (6). These events alter insulin responsiveness of liver, skeletal muscle and adipose tissue exacerbating whole body insulin resistance $(62,63)$. Inflammatory processes have also been described in the brain in the context of diet induced obesity. HFD triggers local immune responses in the $\mathrm{MBH}$ resulting in the production of proinflammatory cytokines and neuronal injury affecting energy homeostasis control and hypothalamic insulin sensitivity $(4,4,15,16,61,64,65)$. Accordingly, recent studies reported that genetic disruption of key inflammatory pathways in the hypothalamus, such as TLR4/MyD88 or IKKb/NF-kB pathways, is protective against the metabolic complications induced by HFD including hypothalamic insulin resistance $(64,66,67)$. This brings further arguments for the role of hypothalamic inflammation as an important contributor of HFD-associated hypothalamic insulin resistance.

\section{MOLECULAR BASIS OF HYPOTHALAMIC INFLAMMATION AND INSULIN RESISTANCE}

At the molecular levels, IKK $\beta / \mathrm{NF}-\mathrm{kB}$ inflammatory pathways have been described to be critical in the development and progression of hypothalamic insulin resistance. Indeed, inactivation of IKK $\beta / \mathrm{NF}-\mathrm{kB}$ signaling in neurons, astrocytes or microglia of the $\mathrm{MBH}$ protects against HFD-induced obesity, glucose intolerance and hypothalamic insulin resistance $(66,68-70)$. Moreover, elevated NF-kB signaling in the hypothalamus of HFD rodents, triggers endoplasmic reticulum (RE) stress which promotes hypothalamic insulin resistance leading to the acceleration of obesity and T2D disease progression $(66,71-75)$. The activation of NF-kB signaling also induces hypothalamic expression of SOCS3 which impairs insulin-dependent phosphorylation of Insulin receptor and its downstream signaling $(66,68,76)$. SOCS3 also targets IRS1/2 for proteasomal degradation (76). Hence, NF-kBdependent upregulation of SOCS3 could thus link hypothalamic inflammation to insulin resistance. Like SOCS3, the PTP-1B is another signaling protein involved in the negative regulation of insulin signaling. HFD up-regulates hypothalamic PTP-1B inhibiting then insulin-mediated anorexigenic effects by insulin receptor dephosphorylation (56, 77-80). Interestingly, neuronspecific deletion of PTP-1B in mice enhanced hypothalamic insulin sensitivity and prevents HFD-induced obesity and related metabolic dysfunctions (81-83). PTP-1B deficiency also attenuates HFD-induced hypothalamic inflammation suggesting a functional link between inflammatory pathways and PTP-1B activation at the neuronal level $(56,80)$.

JNK signaling is another pathway proposed to be critical for the development of obesity associated hypothalamic insulin resistance. Obesity-dependent activation of JNK signaling was shown to impair insulin signaling (84). JNK promotes the serine phosphorylation of IRS-1 that inhibits insulin-dependent IRS- 1 tyrosine phosphorylation and downstream signaling (85, 86). JNK deficiency in the brain protects against HFD-induced insulin resistance (87). Moreover, central administration of JNK inhibitors restores hypothalamic insulin signaling and improves impaired glucose homeostasis under HFD conditions (88).

ER stress and the unfolded protein response (UPR) also contribute to HFD-induced hypothalamic inflammation and insulin resistance (89-92). ER stress results from the deficit in protein folding capacity, and increased accumulation of unfolded protein in the ER lumen $(91,92)$. Prolonged ER stress leads to the activation of UPR signaling pathways in order to restore ER homeostasis $(91,92)$. The deleterious effects of ER stress and UPR on metabolic regulation in peripheral tissues $(75,89,93-95)$ as well as in the hypothalamus $(66,90,96)$ are well-documented. Recent evidence reported that IKK $\beta / N F-$ $\kappa \mathrm{B}$ and JNK pathway link UPR/ER stress to obesity-induced inflammation and insulin resistance $(7,64,95)$. Accordingly, the activation of IKK $\beta / \mathrm{NF}-\kappa \mathrm{B}$ in the $\mathrm{MBH}$ was reported to increase ER stress and related metabolic disorders including insulin resistance $(89,90,94)$. Conversely, neuron-specific deletion of $\mathrm{IKKb}$ in mice is associated with reduced UPR signaling (66). These observations support the critical role of the ER stress and UPR pathway in the onset of metabolic inflammation and insulin resistance notably in the hypothalamus.

Inflammatory responses induced by HFD are also mediated by TLRs known to be involved in innate immunity (25, 97). At the molecular levels, TLRs stimulation results in the activation of several signaling pathways such as $\mathrm{Ikkb} / \mathrm{NFkB}$, JNK/AP-1 signaling, and MAP kinases, including ERK1/2, JNK, and $\mathrm{p} 38$, promoting then the expression of proinflammatory cytokines notably IL1 $\beta$, IL6, and TNF $\alpha$ (25, 97-99). Among the different members of the TLR family, TLR4 is considered as a major contributor of obesity-induced inflammation and insulin resistance $(26,27,100)$. TLR4 expression is increased in obese mice and humans and positively correlates with insulin resistance (26). In obesity, TLR4 is considered as the main target for saturated fatty acids in the hypothalamus and peripheral tissues that triggers inflammatory response and endoplasmic 
reticulum stress promoting whole body insulin resistance (15). Recently, it has been shown that Fetuin A, a glycoprotein mainly produced by liver and adipose tissue, is required for FFAsdependent activation of TLR4. It acts as an endogenous ligand for TLR4 that bridges FFAs and TLR4 promoting inflammation and insulin resistance (101). The implication of TLR4 in obesity was further evidenced by studies reporting that TLR4 knockdown or its pharmacological inhibition, protect mice from diet induced inflammation and insulin resistance (102-105). Furthermore, brain specific deletion of MyD88 (myeloid differentiation factor), a downstream mediator of TLR4 signaling, in mice also prevent HFD-induced obesity and associated leptin and insulin resistance (67). Accordingly, recent evidence reported that the knockdown of TLR4 in the arcuate nucleus protects rats from dietinduced weight gain, glucose intolerance and peripheral insulin resistance (106). Additionally, it has been shown that TLR4mediated microglia signaling pathway is critical for the control of ARC neuronal activity and feeding behavior (107). Collectively, these data strongly demonstrate the implication of brain TLR4 signaling in the pathogenesis of obesity, inflammation and insulin resistance. Nevertheless, some reports do not support such a role of TLR4 in obesity and associated metabolic dysfunctions $(108,109)$. These discrepancies can arise from the animal models and the composition of HFD used, as well as from experimental conditions (i.e., animal age, time of exposure to HFD etc...). These contradictory data also highlight that, besides TLR4 signaling, other pathways are critically involved in obesity-associated inflammation and insulin resistance.

\section{ROLE OF CENTRAL RESISTIN TLR4 SIGNALING PATHWAY IN THE DEVELOPMENT OF HYPOTHALAMIC INFLAMMATION AND INSULIN RESISTANCE}

Even though the mechanisms underlying obesity-induced hypothalamic inflammation are still not fully characterized, it is now recognized that HFD promotes both central and peripheral inflammation through the increase of circulating levels of deleterious adipokines and proinflammatory cytokines originated from the adipose tissue $(4-6,17)$. Among these adipokines, resistin is described as a hormone linking obesity to type 2 diabetes $(110,111)$. Resistin is mainly secreted from adipose tissue in rodents and macrophages in humans (112, 113). Circulating levels of resistin positively correlate with obesity in rodents, promoting both inflammation and insulin resistance (114-117). In rodents, peripheral overexposure to resistin impairs insulin responsiveness (118-120). Conversely, loss of resistin or infusion of resistin antibodies improves peripheral insulin sensitivity $(17,121-123)$. Although resistin has been conclusively linked to the development of obesity and insulin resistance in rodents, disagreement persists regarding the pathogenic role of resistin in human obesity. Several studies support the positive relationship between insulin resistance and elevated plasma resistin levels in obese and type 2 diabetic individuals (124-126), whereas other studies have shown contradictory findings $(127,128)$. Beside its role in obesity and insulin resistance, resistin is greatly implicated in proinflammatory processes which are causally involved in the development of insulin resistance in both rodents and humans $(110,111,129-131)$. Resistin regulates the production of key pro-inflammatory cytokines, such as $\mathrm{TNF} \alpha$ and IL6, through the activation of NF- $\kappa \mathrm{B}$ signaling pathways in macrophages contributing to profound alterations of peripheral insulin signaling pathways resulting in an insulin-resistant state (17, $110,129,130,132,133)$. Previous studies showed that resistin is also expressed in the hypothalamus (134). Interestingly, central resistin activates hypothalamic neurons, and modulates food intake, glucose homeostasis and lipid metabolism in addition to the alteration of liver insulin sensitivity (135138), suggesting an important role of hypothalamic resistin on the control of energy homeostasis and peripheral insulin sensitivity. Nevertheless, the role of resistin on the development of brain inflammation and insulin resistance remains poorly documented. At the molecular level, the resistin receptor remains uncharacterized. However, recent investigations reported TLR4 as a potential candidate for human resistin. TLR4 was first reported to mediate the proinflammatory effects of resistin in human myeloid and epithelial cells (19). TLR4 was also reported to mediate resistin effects on breast cancer progression (139). Recently, it has been shown that resistin competes with LPS for binding to TLR4 resulting in the inhibition of LPS-induced proinflammatory responses and the upregulation of anti-inflammatory pathways suggesting a protective role for resistin/TLR4 pathway against endotoxic shock (24). More recently, we reported that resistin acts within the hypothalamus through the activation of TLR4 receptor and its downstream signaling, promoting both hypothalamic and peripheral inflammation, leading consequently to the impairment of insulin, adiponectin and FGF21 signaling in the hypothalamus and peripheral insulin-sensitive tissues $(20,21)$.

\section{BY WHICH MECHANISMS RESISTIN PROMOTES HYPOTHALAMIC INSULIN RESISTANCE (FIGURE 1)?}

Resistin directly binds to TLR4 in the hypothalamus, promoting the recruitment of the adaptors proteins MyD88 and TIRAP and the activation of downstream signaling pathways. The activation of Resistin/TLR4 signaling impairs hypothalamic insulin responsiveness through the alteration of the insulin-mediated insulin receptor (IR), AKT, and ERK1/2 phosphorylations. This could be attributed to the resistin-dependent downregulation of IR as well as the upregulation of the hypothalamic expression of SOCS-3 and PTP1B, known as key negative modulators of insulin signaling $(56,76)$. Resistin-dependent upregulation of the serine phosphorylation of IRS-1 may also contribute to the impairment of hypothalamic insulin signaling through the activation of the serine kinases JNK and p38 MAPK), which are reported to promote the serine phosphorylation of IRS-1 leading to insulin resistance $(85,86,140)$. Moreover, Resistin triggers hypothalamic inflammation as evidenced 


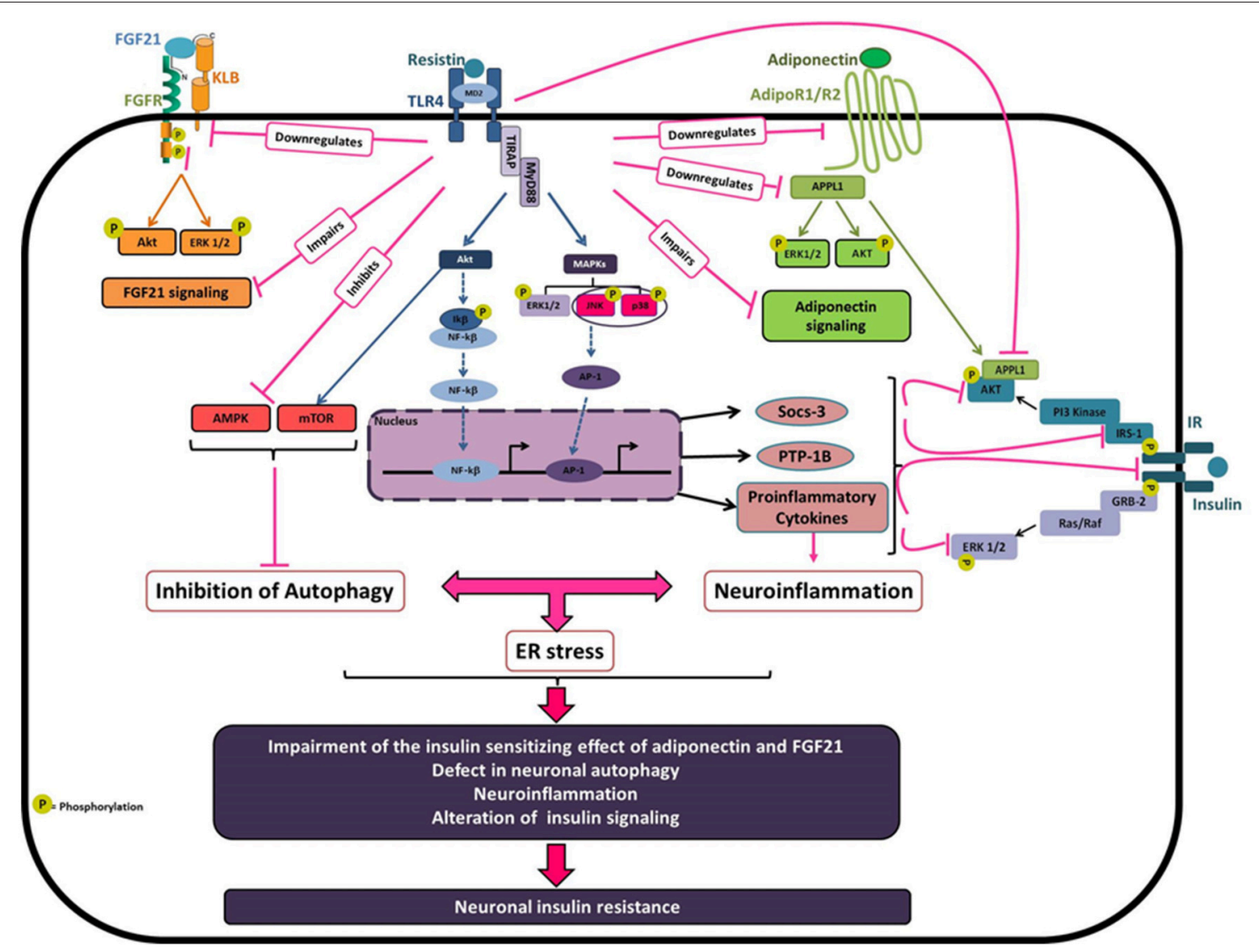

FIGURE 1 | Molecular basis of resistin-dependent neuronal insulin resistance. Obesity is associated with elevated circulating resistin which may reach the hypothalamus leading to hypothalamic inflammation and insulin resistance. Resistin binding to TLR4 result in recruitment of two adaptor-associated proteins TIRAP and MyD88 that leads to the activation of different downstream signaling pathways especially Akt, ERK1/2, JNK, and p38MAPK. Once triggered, Resistin/TLR4 signaling decreases both IR and IRS expression and activity by the downregulation in tyrosine phosphorylation. In agreement with that, resistin upregulates the negative regulators of insulin signaling SOCS-3, and PTP-1B, and activates the MAP kinases JNK and p38 which promotes the phosphorylation of IRS1/2 on serine 307 resulting in the desensitization of insulin signaling. Resistin/TLR4 signaling also promotes neuronal inflammation, at least in part via the activation of the transcription factors AP-1 and NF-kB leading to the upregulation of proinflammatory cytokines notably, IL-6, TNF $\alpha$, and IL-1 $\beta$, which interferes with insulin signaling promoting neuronal insulin resistance. Resistin, via TLR4, also decreases neuronal autophagy, through to the inhibition of AMPK phosphorylation and the activation of Akt/mTOR, which could promote neuronal ER stress and inflammation leading to an amplification loop. Besides, resistin-dependent neuronal insulin resistance could also be attributed to the impairment of both adiponectin and FGF21 signaling known as insulin-sensitizing hormones. Resistin decreases the expression levels of adiponectin receptors AdipoR1/R2 and promotes the downregulation of the adaptor protein APPL1, which is implicated in AdipoRs signaling contributing to the insulin-sensitizing effect of adiponectin. Additionally, resistin reduces the expression of FGF21 and its receptor components FGFR1 and KLB that contribute to the impairment of FGF21 signaling and its beneficial effects on insulin sensitivity.

by the upregulation of the hypothalamic expression of proinflammatory cytokines such as IL6, and the activation of JNK and p38 MAPK signaling pathways known to promote inflammatory response (20). It is noteworthy that HFD-induced activation of microglia and astrocytes is critically involved in the development of hypothalamic inflammation and associated metabolic dysfunctions including insulin resistance $(16,69,141-$ 143). This leads to reactive gliosis evidenced by the proliferation and recruitment of activated astrocytes and microglia in the $\mathrm{MBH}$ amplifying hypothalamic inflammatory response $(16,144-146)$. Since resistin has strong effect on hypothalamic inflammation, similar mechanism might be suspected.

Another suggested mechanism is that central resistin might induce hypothalamic insulin resistance through the impairment of adiponectin and FGF21 signaling known as insulin-sensitizing hormones (147-152). Central resistin treatment reduced the expression levels of adiponectin receptors AdipoR1/R2 in the hypothalamus of mice and rats and promotes the downregulation of the adaptor protein APPL1 (21). Indeed, APPL1 is implicated in AdipoRs signaling contributing to the insulin-sensitizing effect of adiponectin $(147,153)$. Resistin-dependent downregulation of APPL1 enhanced Akt association with its endogenous inhibitors TRB3 inhibiting then insulin-mediated Akt signaling (21). Additionally, central resistin treatment markedly reduced hypothalamic expression of FGF21 and its receptors FGFR1 and KLB that could promote the impairment of hypothalamic FGF21 signaling and its beneficial effects on insulin sensitivity. Accordingly, resistin overexposure directly impairs both FGF21 
and adiponectin signaling in human and mouse neuronal cells. Interestingly, the knockdown of TLR4 prevents resistindependent impairment of adiponectin and FGF21 signaling in mice and neuronal cells suggesting a critical role of TLR4 in mediating resistin effects (21).

Other candidate for resistin downstream effects on hypothalamic insulin sensitivity could be the alteration of neuronal autophagy. In fact, the disruption of autophagy in the hypothalamic neurons is critically involved in diet-induced obesity and associated hypothalamic inflammation and insulin resistance $(16,154-158)$. Interestingly, in neuronal cells, resistin overexposure decreases neuronal autophagy through the repression of several autophagy markers, especially LC3, ATG7, and Beclin-1. At the molecular levels, resistin exerts its effects via the activation of TLR4 signaling leading to the inhibition of AMPK phosphorylation and the activation of Akt/mTOR which regulate autophagy (22). These results were validated in mice, where resistin treatment decreases hypothalamic expression of key autophagy markers. In particular, resistin strongly diminished LC3 labeling in the arcuate nucleus through a mechanism involving TLR4 signaling (22). All together, these data clearly reveal resistin/TLR4 as a new regulatory pathway of neuronal autophagy, and suggest that resistin-dependent neuronal autophagy could be a key contributor of hypothalamic inflammation and insulin resistance.

\section{CONCLUSION}

Obesity is associated with low grade inflammation which occurs in peripheral metabolic tissues, resulting in whole body insulin resistance, but also in the hypothalamus causing local

\section{REFERENCES}

1. Heindel JJ. Endocrine disruptors and the obesity epidemic. Toxicol Sci. (2003) 76:247-9. doi: 10.1093/toxsci/kfg255

2. Heindel JJ. Role of exposure to environmental chemicals in the developmental basis of disease and dysfunction. Reprod Toxicol. (2007) 23:257-9. doi: 10.1016/j.reprotox.2007.01.006

3. Calle EE, Kaaks R. Overweight, obesity and cancer: epidemiological evidence and proposed mechanisms. Nat Rev Cancer. (2004) 4:579-91. doi: $10.1038 / \mathrm{nrc1} 1408$

4. Thaler JP, Schwartz MW. Inflammation and obesity pathogenesis: the hypothalamus heats up. Endocrinology. (2010) 151:4109-15. doi: 10.1210/en.2010-0336

5. Kahn BB, Flier JS. Obesity and insulin resistance. J Clin Invest. (2000) 106:473-81. doi: 10.1172/JCI10842

6. Wellen KE, Hotamisligil GS. Obesity-induced inflammatory changes in adipose tissue. J Clin Invest. (2003) 112:1785-8. doi: 10.1172/JCI20514

7. Gregor MF, Hotamisligil GS. Inflammatory mechanisms in obesity. Annu Rev Immunol. (2011) 29:415-45. doi: 10.1146/annurev-immunol-031210-101322

8. De Souza CT, Araujo EP, Bordin S, Ashimine R, Zollner RL, Boschero AC, et al. Consumption of a fat-rich diet activates a proinflammatory response and induces insulin resistance in the hypothalamus. Endocrinology. (2005) 146:4192-9. doi: 10.1210/en.2004-1520

9. Irani BG, Dunn-Meynell AA, Levin BE. Altered hypothalamic leptin, insulin, and melanocortin binding associated with moderate-fat impairment of insulin signaling and sensitivity. Our recent findings evidenced that central Resistin/TLR4 signaling pathway promotes the onset of hypothalamic inflammation and insulin resistance. Despite these evidences, further studies are needed to clarify the specific role of resistin produced within the hypothalamic neurons as compared to that produced in the periphery, and to identify the neural circuitries mediating resistin effects within hypothalamic nuclei. Indeed, it is also necessary to elucidate the role of resistin/TLR-4 signaling pathway in hypothalamic astrocytes and microglia cells, which are critically involved in the onset of hypothalamic inflammation. Further investigations are needed to clearly decipher regulatory mechanisms involved in hypothalamic resistin/TLR4 signaling in the context of obesity. This will constitute a major step to understand the molecular mechanisms underlying the onset of obesity-induced neuroinflammation, and will identify new potential therapeutic targets to overcome obesity-associated hypothalamic inflammation and related metabolic disorders.

\section{AUTHOR CONTRIBUTIONS}

YB wrote the manuscript and produced the final version. MT contributed to the redaction and reviewed the manuscript.

\section{ACKNOWLEDGMENTS}

We wish to thanks NMPA lab members for their support, especially Sarah AL Rifai, Alexandre Coralie, Laure Riffault, Delphine Crepin, and Ghislaine Poizat. This work was supported by CNRS, the University Paris Sud and the University Paris Saclay (FRANCE). diet and predisposition to obesity. Endocrinology. (2007) 148:310-6. doi: 10.1210/en.2006-1126

10. Könner AC, Klöckener T, Brüning JC. Control of energy homeostasis by insulin and leptin: targeting the arcuate nucleus and beyond. Physiol Behav. (2009) 97:632-8. doi: 10.1016/j.physbeh.2009.03.027

11. Belgardt BF, Brüning JC. CNS leptin and insulin action in the control of energy homeostasis. Ann N Y Acad Sci. (2010) 1212:97-113. doi: 10.1111/j.1749-6632.2010.05799.x

12. Horvath TL, Bruning JC. Developmental programming of the hypothalamus: a matter of fat. Nat Med. (2006) 12:52-3. doi: 10.1038/nm0106-52

13. Vogt MC, Paeger L, Hess S, Steculorum SM, Awazawa M, Hampel B, et al. Neonatal insulin action impairs hypothalamic neurocircuit formation in response to maternal high-fat feeding. Cell. (2014) 156:495-509. doi: 10.1016/j.cell.2014.01.008

14. Kirk SL, Samuelsson AM, Argenton M, Dhonye H, Kalamatianos T, Poston L, et al. Maternal obesity induced by diet in rats permanently influences central processes regulating food intake in offspring. PLoS ONE. (2009) 4:e5870. doi: 10.1371/journal.pone.0005870

15. Milanski M, Degasperi G, Coope A, Morari J, Denis R, Cintra $\mathrm{DE}$, et al. Saturated fatty acids produce an inflammatory response predominantly through the activation of TLR4 signaling in hypothalamus: implications for the pathogenesis of obesity. J Neurosci. (2009) 29:359-70. doi: 10.1523/JNEUROSCI.2760-08.2009

16. Thaler JP, Yi CX, Schur EA, Guyenet SJ, Hwang BH, Dietrich MO, et al. Obesity is associated with hypothalamic injury in rodents and humans. J Clin Invest. (2012) 122:153-62. doi: 10.1172/JCI59660 
17. Olefsky JM, Glass CK. Macrophages, inflammation, and insulin resistance. Аnnu Rev Physiol. (2010) 72:219-46. doi: 10.1146/annurev-physiol-021909-135846

18. Steppan CM, Bailey ST, Bhat S, Brown EJ, Banerjee RR, Wright CM, et al. The hormone resistin links obesity to diabetes. Nature. (2001) 409:307-12. doi: $10.1038 / 35053000$

19. Tarkowski A, Bjersing J, Shestakov A, Bokarewa MI. Resistin competes with lipopolysaccharide for binding to toll-like receptor 4. J Cell Mol Med. (2010) 4:1419-31. doi: 10.1111/j.1582-4934.2009.00899.x

20. Benomar Y, Gertler A, De Lacy P, Crépin D, Hamouda HO, Riffault L, et al. Central resistin overexposure induces insulin resistance through toll-like receptor 4. Diabetes. (2013) 62:102-14. doi: 10.2337/db12-0237

21. Benomar Y, Amine H, Crépin D, Al Rifai S, Riffault L, Gertler A, et al. Central resistin/TLR4 impairs adiponectin signaling contributing to insulin and FGF21 resistance. Diabetes. (2016) 65:913-26. doi: 10.2337/db15-1029

22. Miao J, Benomar Y, Al Rifai S, Poizat G, Riffault L, Crépin D, et al. Resistin inhibits neuronal autophagy through Toll-like receptor 4. J Endocrinol. (2018) 238:77-89. doi: 10.1530/JOE-18-0096

23. Jiang Y, Lu L, Hu Y, Li Q, An C, Yu X, et al. Resistin induces hypertension and insulin resistance in mice via a TLR4-dependent pathway. Sci Rep. (2016) 6:22193. doi: 10.1038/srep22193

24. Jang JC, Li J, Gambini L, Batugedara HM, Sati S, Lazar MA, et al. Human resistin protects against endotoxic shock by blocking LPSTLR4 interaction. Proc Natl Acad Sci USA. (2017) 114:E10399-408. doi: 10.1073/pnas.1716015114

25. Mogensen TH. Pathogen recognition and inflammatory signaling in innate immune defenses. Clin Microbiol Rev. (2009) 22:240-73. doi: 10.1128/CMR.00046-08

26. Könner A, Brüning J. Toll-like receptors: linking inflammation to metabolism. Trends Endocrinol Metab. (2011) 22:16-23. doi: $10.1016 /$ j.tem.2010.08.007

27. Fresno M, Alvarez R, Cuesta N. Toll-like receptors, inflammation, metabolism and obesity. Arch Physiol Biochem. (2011) 117:151-64. doi: 10.3109/13813455.2011.562514

28. Kalra SP, Dube MG, Pu S, Xu B, Horvath TL, Kalra PS. Interacting appetiteregulating pathways in the hypothalamic regulation of body weight. Endocr Rev. (1999) 20:68-100. doi: 10.1210/er.20.1.68

29. Schwartz MW, Woods SC, Porte D Jr, Seeley RJ, Baskin DG. Central nervous system control of food intake. Nature. (2000) 404:661-71. doi: 10.1038/35007534

30. Cone RD, Cowley MA, Butler AA, Fan W, Marks DL, Low MJ. The arcuate nucleus as a conduit for diverse signals relevant to energy homeostasis. Int J Obes Relat Metab Disord. (2001) 25(Suppl. 5):S63-7. doi: 10.1038/sj.ijo.0801913

31. Lenard NR, Berthoud HR. Central and peripheral regulation of food intake and physical activity: pathways and genes. Obesity. (2008) 16(Suppl. 3):S11-22. doi: 10.1038/oby.2008.511

32. Banks WA. The source of cerebral insulin. Eur J Pharmacol. (2004) 490:5-12. doi: 10.1016/j.ejphar.2004.02.040

33. Schwartz M, Sipols AJ, Marks JL, Sanacora G, White JD, Sheurink A, et al. Inhibition of hypothalamic neuropeptide $\mathrm{Y}$ gene expression by insulin. Endocrinology. (1992) 130:3608-16. doi: 10.1210/endo.130.6. 1597158

34. Benoit SC, Air EL, Coolen LM, Strauss R, Jackman A, Clegg DJ, et al. The catabolic action of insulin in the brain is mediated by melanocortins. J Neurosci. (2002) 22:9048-52. doi: 10.1523/JNEUROSCI.22-20-09048.2002

35. Niswender KD, Morrison CD, Clegg DJ, Olson R, Baskin DG, Myers MG Jr, et al. Insulin activation of phosphatidylinositol 3-kinase in the hypothalamic arcuate nucleus: a key mediator of insulin-induced anorexia. Diabetes. (2003) 52:227-31. doi: 10.2337/diabetes.52.2.227

36. Choudhury AI, Heffron H, Smith MA, AlQassab H, Xu AW, Selman $\mathrm{C}$, et al. The role of insulin receptor substrate 2 in hypothalamic and beta cell function. J Clin Invest. (2005) 115:940-50. doi: 10.1172/JCI 24445

37. Könner AC, Janoschek R, Plum L, Jordan SD, Rother E, Ma X, et al. Insulin action in AgRP-expressing neurons is required for suppression of hepatic glucose production. Cell Metab. (2007) 5:438-49. doi: 10.1016/j.cmet.2007.05.004
38. Obici S, Zhang BB, Karkanias G, Rossetti L. Hypothalamic insulin signalling is required for inhibition of glucose production. Nat Med. (2002) 8:1376-82. doi: $10.1038 / \mathrm{nm} 1202-798$

39. Perrin C, Knauf C, Burcelin R. Intracerebroventricular infusion of glucose, insulin, and the adenosine monophosphate-activated kinase activator, 5-aminoimidazole-4-carboxamide-1-beta-D-ribofuranoside, controls muscle glycogen synthesis. Endocrinology. (2004) 145:4025-33. doi: 10.1210/en.2004-0270

40. KochL, Wunderlich FT, Seibler J, Konner AC, Hampel B, Irlenbusch S, et al. Central insulin action regulates peripheral glucose and fat metabolism in mice. J Clin Invest. (2008) 118:2132-47. doi: 10.1172/JCI31073

41. Shin AC, Filatova N, Lindtner C, Chi T, Degann S, Oberlin D, et al. Insulin receptor signaling in POMC, but Not AgRP, neurons controls adipose tissue insulin action. Diabetes. (2017) 66:1560-71. doi: 10.2337/db16-1238

42. Sahu A. A hypothalamic role in energy balance with special emphasis on leptin. Endocrinology. (2004) 145:2613-20. doi: 10.1210/en.2004-0032

43. Bjorbaek C, Kahn BB. Leptin signaling in the central nervous system and the periphery. Recent Prog Horm Res. (2004) 59:305-31. doi: 10.1210/rp.59.1.305

44. Sandoval DA, Davis SN. Leptin metabolic control and regulation. J Diabetes Complications. (2003) 17:108-13. doi: 10.1016/S1056-8727(02)00167-8

45. Cusin I, Zakrzewska KE, Boss O, Muzzin P, Giacobino JP, Ricquier D, et al. Chronic central leptin infusion enhances insulin stimulated glucose metabolism and favors the expression of uncoupling proteins. Diabetes. (1998) 47:1014-9. doi: 10.2337/diabetes.47.7.1014

46. Berthou F, Rouch C, Gertler A, Gerozissis K, Taouis M. Chronic central leptin infusion differently modulates brain and liver insulin signaling. Mol Cell Endocrinol. (2011) 337:89-95. doi: 10.1016/j.mce.2011.02.005

47. Niswender KD, Schwartz MW. Insulin and leptin revisited: adiposity signals with overlapping physiological and intracellular signaling capabilities. Front Neuroendocrinol. (2003) 24:1-10. doi: 10.1016/S0091-3022(02)00105-X

48. Benomar Y, Roy AF, Aubourg A, Djiane J, Taouis M. Cross down-regulation of leptin and insulin receptor expression and signalling in a human neuronal cell line. Biochem J. (2005) 388(Pt 3):929-39. doi: 10.1042/BJ20041621

49. Banks WA, Jaspan JB, Kastin AJ. Selective, physiological transport of insulin across the blood-brain barrier: novel demonstration by species-specific radioimmunoassays. Peptides. (1997) 18:1257-62. doi: 10.1016/S0196-9781(97)00198-8

50. Kaiyala KJ, Prigeon RL, Kahn SE, Woods SC, Schwartz MW. Obesity induced by a high-fat diet is associated with reduced brain insulin transport in dogs. Diabetes. (2000) 49:1525-33. doi: 10.2337/diabetes.49.9.1525

51. Urayama A, Banks WA. Starvation and triglycerides reverse the obesityinduced impairment of insulin transport at the blood brain barrier. Endocrinology. (2008) 149:3592-7. doi: 10.1210/en.2008-0008

52. Carvalheira JB, Ribeiro EB, Araujo EP, Guimaraes RB, Telles MM, Torsoni $\mathrm{M}$, et al. Selective impairment of insulin signalling in the hypothalamus of obese Zucker rats. Diabetologia. (2003) 46:1629-40. doi: 10.1007/s00125-003-1246-x

53. Ikeda H, West DB, Pustek JJ, Figlewicz DP, Greenwood MR, Porte $\mathrm{D}$ Jr, et al. Intraventricular insulin reduces food intake and body weight of lean but not obese Zucker rats. Appetite. (1986) 7:381-6. doi: 10.1016/S0195-6663(86)80006-X

54. Hallschmid M, Benedict C, Schultes B, Born J, Kern W. Obese men respond to cognitive but not to catabolic brain insulin signaling. Int J Obes. (2008) 32:275-82. doi: 10.1038/sj.ijo.0803722

55. Heni M, Wagner R, Kullmann S, Veit R, Mat Husin H, Linder K, et al. Central insulin administration improves whole-body insulin sensitivity via hypothalamus and parasympathetic outputs in men. Diabetes. (2014) 63:4083-8. doi: 10.2337/db14-0477

56. Zabolotny JM, Kim Y-B, Welsh LA, Kershaw EE, Neel BG, Kahn BB. Proteintyrosine phosphatase $1 \mathrm{~B}$ expression is induced by inflammation in vivo. J Biol Chem. (2008) 283:14230-41. doi: 10.1074/jbc.M800061200

57. Benoit SC, Kemp CJ, Elias CF, Abplanalp W, Herman JP, Migrenne S, et al. Palmitic acid mediates hypothalamic insulin resistance by altering PKCtheta subcellular localization in rodents. J Clin Invest. (2009) 119:2577-89. doi: 10.1172/JCI36714

58. Bjørbaek C, El-Haschimi K, Frantz JD, Flier JS. The role of SOCS3 in leptin signaling and leptin resistance. J Biol Chem. (1999) 274:30059-65. doi: $10.1074 /$ jbc. 274.42 .30059 
59. Burgos-Ramos E, Chowen JA, Arilla-Ferreiro E, Canelles S, Argente J, Barrios V. Chronic central leptin infusion modifies the response to acute central insulin injection by reducing the interactionoftheinsulinreceptorwithIRS2andincreasingitsassociation $\begin{array}{llll}\text { with SOCS3. } J \text { Neurochem. (2011) 117:175-85. } & \end{array}$ doi: 10.1111/j.1471-4159.2011.07191.x

60. Koch C, Augustine RA, Steger J, Ganjam GK, Benzler J, Pracht C, et al. Leptin rapidly improves glucose homeostasis in obese mice by increasing hypothalamic insulin sensitivity. J Neurosci. (2010) 30:16180-7. doi: 10.1523/JNEUROSCI.3202-10.2010

61. Jais A, Brüning JC. Hypothalamic inflammation in obesity and metabolic disease. J Clin Invest. (2017) 127:24-32. doi: 10.1172/JCI88878

62. de Luca C, Olefsky JM. Inflammation and insulin resistance. FEBS Lett. (2008) 582:97-105. doi: 10.1016/j.febslet.2007.11.057

63. Lumeng CN, Saltiel AR. Inflammatory links between obesity and metabolic disease. J Clin Invest. (2011) 121:2111-7. doi: 10.1172/JCI57132

64. Valdearcos $\mathrm{M}, \mathrm{Xu} \mathrm{AW}$, Koliwad SK. Hypothalamic inflammation in the control of metabolic function. Annu Rev Physiol. (2015) 77:131-60. doi: 10.1146/annurev-physiol-021014-071656

65. Kälin S. Heppner FL, Bechmann I, Prinz M, Tschöp MH, Yi CX. Hypothalamic innate immune reaction in obesity. Nat Rev Endocrinol. (2015) 11:339-51. doi: 10.1038/nrendo.2015.48

66. Zhang X, Zhang G, Zhang H, Karin M, Bai H, Cai D. Hypothalamic IKK $\beta / N F-K B$ and ER stress link overnutrition to energy imbalance and obesity. Cell. (2008) 135:61-73. doi: 10.1016/j.cell.2008.07.043

67. Kleinridders A, Schenten D, Könner AC, Belgardt BF, Mauer J, Okamura T, et al. MyD88 signaling in the CNS is required for development of fatty acid-induced leptin resistance and diet-induced obesity. Cell Metab. (2009) 10:249-59. doi: 10.1016/j.cmet.2009.08.013

68. Benzler J, Ganjam GK, Pretz D, Oelkrug R, Koch CE, Legler K, et al. Central inhibition of IKK $\beta / \mathrm{NF}-\mathrm{\kappa B}$ signaling attenuates high-fat dietinduced obesity and glucose intolerance. Diabetes. (2015) 64:2015-27. doi: $10.2337 / \mathrm{db} 14-0093$

69. Douglass JD, Dorfman MD, Fasnacht R, Shaffer LD, Thaler JP. Astrocyte IKK $\beta / \mathrm{NF}-\mathrm{KB}$ signaling is required for diet-induced obesity and hypothalamic inflammation. Mol Metab. (2017) 6:366-73. doi: 10.1016/j.molmet.2017.01.010

70. Valdearcos M, Douglass JD, Robblee MM, Dorfman MD, Stifler DR, Bennett ML, et al. Microglial inflammatory signaling orchestrates the hypothalamic immune response to dietary excess and mediates obesity susceptibility. Cell Metab. (2017) 26:185-97.e3. doi: 10.1016/j.cmet.2017.05.015

71. Chaudhari N, Talwar P, Parimisetty A, Lefebvre d'Hellencourt C, Ravanan P. A molecular web: endoplasmic reticulum stress, inflammation, and oxidative stress. Front Cell Neurosci. (2014) 8:213. doi: 10.3389/fncel.2014.00213

72. Hotamisligil GS. Inflammation and metabolic disorders. Nature. (2006) 444:860-7. doi: 10.1038/nature05485

73. Won JC, Jang PG, Namkoong C, Koh EH, Kim SK, Park JY, et al. Central administration of an endoplasmic reticulum stress inducer inhibits the anorexigenic effects of leptin and insulin. Obesity. (2009) 17:1861-5. doi: 10.1038/oby.2009.194

74. Pimentel GD, Ganeshan K, Carvalheira JBC. Hypothalamic inflammation and the central nervous system control of energy homeostasis. Mol Cell Endocrinol. (2014) 397:15-22. doi: 10.1016/j.mce.2014.06.005

75. Ozcan U, Cao Q, Yilmaz E, Lee AH, Iwakoshi NN, Ozdelen E, et al. Endoplasmic reticulum stress links obesity, insulin action, and type 2 diabetes. Science. (2004) 306:457-61. doi: 10.1126/science.1103160

76. Howard JK, Flier JS. Attenuation of leptin and insulin signaling by SOCS proteins. Trends Endocrinol Metab. (2006) 17:365-71. doi: 10.1016/j.tem.2006.09.007

77. White CL, Whittington A, Barnes MJ, Wang Z, Bray GA, Morrison CD. HF diets increase hypothalamic PTP1B and induce leptin resistance through both leptin-dependent and -independent mechanisms. Am J Physiol Endocrinol Metab. (2009) 296:E291-9. doi: 10.1152/ajpendo.90513.2008

78. Dube N, Tremblay ML. Involvement of the small protein tyrosine phosphatases TC-PTP and PTP1B in signal transduction and diseases: from diabetes, obesity to cell cycle, and cancer. Biochim Biophys Acta. (2005) 1754:108-17. doi: 10.1016/j.bbapap.2005.07.030
79. Zhang ZY, Dodd GT, Tiganis T. Protein tyrosine phosphatases in hypothalamic insulin and leptin signaling. Trends Pharmacol Sci. (2015) 36:661-74. doi: 10.1016/j.tips.2015.07.003

80. Bakke J, Haj FG. Protein-tyrosine phosphatase 1B substrates and metabolic regulation. Semin Cell Dev Biol. (2015) 37:58-65. doi: 10.1016/j.semcdb.2014.09.020

81. Bence KK, Delibegovic M, Xue B, Gorgun CZ, Hotamisligil GS, Neel BG, et al. Neuronal PTP1B regulates body weight, adiposity and leptin action. Nat Med. (2006) 12:917-24. doi: 10.1038/nm1435

82. Banno R, Zimmer D, DeJonghe BC, Atienza M, RakK, Yang W, et al. PTP1B and SHP2 in POMC neurons reciprocally regulate energy balance in mice. $J$ Clin Invest. (2010) 120:720-34. doi: 10.1172/JCI39620

83. Aberdein N, Dambrino RJ, do Carmo JM, Wang Z, Mitchell LE, Drummond HA, et al. Role of PTP1B in POMC neurons during chronic high-fat diet: sex differences in regulation of liver lipids and glucose tolerance. Am J Physiol Regul Integr Comp Physiol. (2018) 314:R478-88. doi: 10.1152/ajpregu.00287.2017

84. Tanti JF, Jager J. Cellular mechanisms of insulin resistance: role of stress-regulated serine kinases and insulin receptor substrates (IRS) serine phosphorylation. Curr Opin Pharmacol. (2009) 9:753-62. doi: 10.1016/j.coph.2009.07.004

85. Aguirre V, Werner ED, Giraud J, Lee YH, Shoelson SE, White MF. Phosphorylation of Ser307 in insulin receptor substrate-1 blocks interactions with the insulin receptor and inhibits insulin action. J Biol Chem. (2002) 277:1531-7. doi: 10.1074/jbc.M101521200

86. Copps KD, White MF. Regulation of insulin sensitivity by serine/threonine phosphorylation of insulin receptor substrate proteins IRS1 and IRS2. Diabetologia. (2012) 55:2565-82. doi: 10.1007/s00125-012-2644-8

87. Belgardt BF, Mauer J, Wunderlich FT, Ernst MB, Pal M, Spohn G, Brönneke HS, et al. Hypothalamic and pituitary c-Jun Nterminal kinase 1 signaling coordinately regulates glucose metabolism. Proc Natl Acad Sci USA. (2010) 107:6028-33. doi: 10.1073/pnas.1001796107

88. Benzler J, Ganjam GK, Legler K, Stöhr S, Krüger M, Steger J, et al. Acute inhibition of central c-Jun $\mathrm{N}$-terminal kinase restores hypothalamic insulin signalling and alleviates glucose intolerance in diabetic mice. J Neuroendocrinol. (2013) 25:446-54. doi: 10.1111/jne.12018

89. Cnop M1, Foufelle F, Velloso LA. Endoplasmic reticulum stress, obesity and diabetes. Trends Mol Med. (2012) 18:59-68. doi: 10.1016/j.molmed.2011.07.010

90. De Felice FG, Ferreira ST. Getting a "GRiP" on hypothalamic endoplasmic reticulum stress to combat obesity. Diabetes. (2017) 66:17-19. doi: $10.2337 /$ dbi16-0057

91. Hampton RY. ER stress response: getting the UPR hand on misfolded proteins. Curr Biol. (2000) 10:R518-21. doi: 10.1016/S0960-9822(00)00583-2

92. Mori K. Tripartite management of unfolded proteins in the endoplasmic reticulum. Cell. (2000) 101:451-4. doi: 10.1016/S0092-8674(00)80855-7

93. Hotamisligil GS. Inflammation and endoplasmic reticulum stress in obesity and diabetes. Int J Obes. (2008) 32 (Suppl. 7):S52-4. doi: 10.1038/ijo.2008.238

94. Hotamisligil GS. Endoplasmic reticulum stress and the inflammatory basis of metabolic disease. Cell. (2010) 140:900-17. doi: 10.1016/j.cell.2010. 02.034

95. Flamment M, Hajduch E, Ferre P, Foufelle F. New insights into ER stressinduced insulin resistance. Trends Endocrinol Metab. (2012) 23:381-90. doi: 10.1016/j.tem.2012.06.003

96. Ozcan L, Ergin A, Lu A, Chung J, Sarkar S, Nie D, et al. Endoplasmic reticulum stress plays a central role in development of leptin resistance. Cell Metab. (2009) 9:35-51. doi: 10.1016/j.cmet.2008.12.004

97. Kawai T, Akira S. The role of pattern-recognition receptors in innate immunity: update on Toll-like receptors. Nat Immunol. (2010) 11:373-84. doi: $10.1038 /$ ni. 1863

98. Jialal I, Kaur H, Devaraj S. Toll-like receptor status in obesity and metabolic syndrome: a translational perspective. J Clin Endocrinol Metab. (2014) 99:39-48. doi: 10.1210/jc.2013-3092

99. Iwasaki A, Medzhitov R. Toll-like receptor control of the adaptive immune responses. Nat Immunol. (2004) 5:987-95. doi: 10.1038/ni1112

100. Rogero MM, Calder PC. Obesity, inflammation, toll-like receptor 4 and fatty acids. Nutrients. (2018) 10:E432. doi: 10.3390/nu10040432 
101. Pal D, Dasgupta S, Kundu R, Maitra S, Das G, Mukhopadhyay S, et al. FetuinA acts as an endogenous ligand of TLR4 to promote lipid-induced insulin resistance. Nat Med. (2012) 18:1279-85. doi: 10.1038/nm.2851

102. Kim F, Pham M, Luttrell I, Bannerman DD, Tupper J, Thaler J, et al. Toll-like receptor-4 mediates vascular inflammation and insulin resistance in diet-induced obesity. Circul Res. (2007) 100:1589-96. doi: 10.1161/CIRCRESAHA.106.142851

103. Poggi M, Bastelica D, Gual P, Iglesias MA, Gremeaux T, Knauf C, et al. $\mathrm{C} 3 \mathrm{H} / \mathrm{HeJ}$ mice carrying a toll-like receptor 4 mutation are protected against the development of insulin resistance in white adipose tissue in response to a high-fat diet. Diabetologia. (2007) 50:1267-76. doi: 10.1007/s00125-007-0654-8

104. Shi H, Kokoeva MV, Inouye K, Tzameli I, Yin H, Flier JS. TLR4 links innate immunity and fatty acid-induced insulin resistance. J Clin Investig. (2006) 116:3015-25. doi: 10.1172/JCI28898

105. Tsukumo DM, Carvalho-Filho MA, Carvalheira JB, Prada PO, Hirabara SM, Schenka AA, et al. Loss-of-function mutation in Toll-like receptor 4 prevents diet-induced obesity and insulin resistance. Diabetes. (2007) 56:1986-98. doi: $10.2337 / \mathrm{db} 06-1595$

106. Zhao $\mathrm{Y}$, Zhang $\mathrm{M}$, Zhao J, Ma $\mathrm{X}$, Huang $\mathrm{T}$, Pang $\mathrm{H}$, et al. Inhibition of TLR4 signalling-induced inflammation attenuates secondary injury after diffuse axonal injury in rats. Mediat Inflamm. (2016) 2016:4706915. doi: 10.1155/2016/4706915

107. Reis WL, Yi CX, Gao Y, Tschöp MH, Stern JE. Brain innate immunity regulates hypothalamic arcuate neuronal activity and feeding behavior. Endocrinology. (2015) 156:1303-15. doi: 10.1210/en.2014-1849

108. Ding Y, Subramanian S, Montes VN, Goodspeed L, Wang S, Han C, et al. Toll-like receptor 4 deficiency decreases atherosclerosis but does not protect against inflammation in obese low-density lipoprotein receptor-deficient mice. Arterioscler Thromb Vasc Biol. (2012) 32:1596-604. doi: 10.1161/ATVBAHA.112.249847

109. Dalby MJ, Aviello G, Ross AW, Walker AW, Barrett P, Morgan PJ. Diet induced obesity is independent of metabolic endotoxemia and TLR4 signalling, but markedly increases hypothalamic expression of the acute phase protein, SerpinA3N. Sci Rep. (2018) 8:15648. doi: 10.1038/s41598-018-33928-4

110. Codoñer-Franch P, Alonso-Iglesias E. Resistin: insulin resistance to malignancy. Clin Chim Acta. (2015) 438:46-54. doi: 10.1016/j.cca.2014.07.043

111. Pine GM, Batugedara HM, Nair MG. Here, there and everywhere: resistinlike molecules in infection, inflammation, and metabolic disorders. Cytokine. (2018) 110:442-51. doi: 10.1016/j.cyto.2018.05.014

112. Savage DB, Sewter CP, Klenk ES, Segal DG, Vidal-Puig A, Considine RV, et al. Resistin/Fizz3 expression in relation to obesity and peroxisome proliferatoractivated receptor-g action in humans. Diabetes. (2001) 50:2199-202. doi: 10.2337/diabetes.50.10.2199

113. Patel L, Buckels AC, Kinghorn IJ, Murdock PR, Holbrook JD, Plumpton C, et al. Resistin is expressed in human macrophages and directly regulated by PPAR gamma activators. Biochem Biophys Res Commun. (2003) 300:472-6. doi: 10.1016/S0006-291X(02)02841-3

114. McTernan PG, Kusminski CM, Kumar S. Resistin. Curr Opin Lipidol. (2006) 17:170-5. doi: 10.1097/01.mol.0000217899.59820.9a

115. Holcomb IN, Kabakoff RC, Chan B, Baker TW, Gurney A, Henzel W, et al. FIZZ1, a novel cysteine-rich secreted protein associated with pulmonary inflammation, defines a new gene family. ЕMBO J. (2000) 19:4046-55. doi: 10.1093/emboj/19.15.4046

116. Reilly MP, Lehrke M, Wolfe ML, Rohatgi A, Lazar MA, Rader DJ. Resistin is an inflammatory marker of atherosclerosis in humans. Circulation. (2005) 111:932-9. doi: 10.1161/01.CIR.0000155620.10387.43

117. Nogueiras R, Gualillo O, Caminos JE, Casanueva FF, Diéguez C. Regulation of resistin by gonadal, thyroid hormone, and nutritional status. Obes Res. (2003) 11:408-14. doi: 10.1038/oby.2003.55

118. Rajala MW, Obici S, Scherer PE, Rossetti L. Adipose-derived resistin and gut derived resistin-like molecule-beta selectively impair insulin action on glucose production. J Clin Invest. (2003) 111:225-30. doi: 10.1172/JCI16521

119. Pravenec M, Kazdova L, Landa V, Zidek V, Mlejnek P, Jansa P, et al. Transgenic and recombinant resistin impair skeletal muscle glucose metabolism in the spontaneously hypertensive rat. J Biol Chem. (2003) 278:45209-15. doi: 10.1074/jbc.M304869200

120. Satoh H, Nguyen MT, Miles PD, Imamura T, Usui I, Olefsky JM. Adenovirusmediated chronic "hyper-resistinemia" leads to in vivo insulin resistance in normal rats. J Clin Invest. (2004) 114:224-31. doi: 10.1172/JCI200420785

121. Muse ED, Obici S, Bhanot S, Monia BP, McKay RA, Rajala MW, et al. Role of resistin in diet-induced hepatic insulin resistance. J Clin Invest. (2004) 114:232-9. doi: 10.1172/JCI200421270

122. Banerjee RR, Rangwala SM, Shapiro JS, Shapiro JS, Rich AS, Rhoades B, et al. Regulation of fasted blood glucose by resistin. Science. (2004) 303:1195-8. doi: $10.1126 /$ science.1092341

123. Qi Y, Nie Z, Lee Y-S, Singhal NS, Scherer PE, Lazar MA, et al. Loss of resistin improves glucose homeostasis in leptin deficiency. Diabetes. (2006) 55:3083-90. doi: 10.2337/db05-0615

124. Silha JV, Krsek M, Skrha JV, Sucharda P, Nyomba BL, Murphy LJ. Plasma resistin, adiponectin and leptin levels in lean and obese subjects: correlations with insulin resistance. Eur J Endocrinol. (2003) 149:331-5. doi: 10.1530/eje.0.1490331

125. Menzaghi C, Coco A, Salvemini L, Thompson R, De Cosmo S, Doria A, et al. Heritability of serum resistin and its genetic correlation with insulin resistance-related features in nondiabetic Caucasians. J Clin Endocrinol Metab. (2006) 91:2792-5. doi: 10.1210/jc.2005-2715

126. Heilbronn L, Rood J, Janderova L, Albu J, Kelley D, Ravussin E, et al. Relationship between serum resistin concentrations and insulin resistance in non-obese, obese, and obese diabetic subjects. J Clin Endocrinol Metab. (2004) 89:1844-8. doi: 10.1210/jc.2003-031410

127. Lee JH, Chan JL, Yiannakouris N, Kontogianni M, Estrada E, Seip $\mathrm{R}$, et al. Circulating resistin levels are not associated with obesity or insulin resistance in humans and are not regulated by fasting or leptin administration: cross-sectional and interventional studies in normal, insulinresistant, and diabetic subjects. J Clin Endocrinol Metab. (2003) 88:4848-56. doi: $10.1210 /$ jc. $2003-030519$

128. Mostafazadeh M, Haiaty S, Rastqar A, Keshvari M. Correlation between resistin level and metabolic syndrome component: a review. Horm Metab Res. (2018) 50:521-36. doi: 10.1055/a-0637-1975

129. Bokarewa M, Nagaev I, Dahlberg L, Smith U, Tarkowski A. Resistin, an adipokine with potent proinflammatory properties. J Immunol. (2005) 174:5789-95. doi: 10.4049/jimmunol.174.9.5789

130. Johnson AM, Olefsky JM. The origins and drivers of insulin resistance. Cell. (2013) 152:673-84. doi: 10.1016/j.cell.2013.01.041

131. Schwartz DR, Lazar MA. Human resistin: found in translation from mouse to man. Trends Endocrinol Metab. (2011) 22:259-65. doi: 10.1016/j.tem.2011.03.005

132. Silswal N, Singh AK, Aruna B, Mukhopadhyay S, Ghosh S, Ehtesham NZ. Human resistin stimulates the proinflammatory cytokines TNF-alpha and IL-12 in macrophages by NFkappaB-dependent pathway. Biochem Biophys Res Commun. (2005) 334:1092-101. doi: 10.1016/j.bbrc.2005.06.202

133. Al Hannan F, Culligan KG. Human resistin and the RELM of Inflammation in diabesity. Diabetol Metab Syndr. (2015) 7:54. doi: 10.1186/s13098-015-0050-3

134. Wilkinson M, Wilkinson D, Wiesner G, Morash B, Ur E. Hypothalamic resistin immunoreactivity is reduced by obesity in the mouse: colocalization with alpha-melanostimulating hormone. Neuroendocrinology. (2005) 81:19-30. doi: 10.1159/000084871

135. Tovar S, Nogueiras R, Tung LY, Castaneda TR, Vázquez MJ, Morris A, et al. Central administration of resistin promotes short-term satiety in rats. Eur J Endocrinol. (2005) 153:R1-5. doi: 10.1530/eje.1.01999

136. Muse ED, Lam TK, Scherer PE, Rossetti L. Hypothalamic resistin induces hepatic insulin resistance. J Clin Invest. (2007) 117:1670-8. doi: 10.1172/JCI30440

137. Vázquez MJ, González CR, Varela L, Lage R, Tovar S, Sangiao-Alvarellos S, et al. Central resistin regulates hypothalamic and peripheral lipid metabolism in a nutritional-dependent fashion. Endocrinology. (2008) 149:4534-43. doi: 10.1210/en.2007-1708

138. Singhal NS, Lazar MA, Ahima RS. Central resistin induces hepatic insulin resistance via neuropeptide Y. J Neurosci. (2007) 27:12924-32. doi: 10.1523/JNEUROSCI.2443-07.2007 
139. Wang $\mathrm{CH}$, Wang PJ, Hsieh YC, Lo S, Lee YC, Chen YC, et al. Resistin facilitates breast cancer progression via TLR4-mediated induction of mesenchymal phenotypes and stemness properties. Oncogene. (2018) 37:589-600. doi: 10.1038/onc.2017.357

140. Hemi R, Yochananov Y, Barhod E, Kasher-Meron M, Karasik A, Tirosh A, et al. p38 mitogen-activated protein kinase-dependent transactivation of ErbB receptor family: a novel common mechanism for stress-induced IRS-1 serine phosphorylation and insulin resistance. Diabetes. (2011) 60:1134-45. doi: 10.2337/db09-1323

141. Douglass JD, Dorfman MD, Thaler JP. Glia: silent partners in energy homeostasis and obesity pathogenesis. Diabetologia. (2017) 60:226-36. doi: 10.1007/s00125-016-4181-3

142. Valdearcos M, Robblee MM, Benjamin DI, Nomura DK, Xu AW, Koliwad SK. Microglia dictate the impact of saturated fat consumption on hypothalamic inflammation and neuronal function. Cell Rep. (2014) 9:2124-38. doi: 10.1016/j.celrep.2014.11.018

143. André C, Guzman-Quevedo O, Rey C, Rémus-Borel J, Clark S, CastellanosJankiewicz A. Inhibiting microglia expansion prevents diet-induced hypothalamic and peripheral inflammation. Diabetes. (2017) 66:908-19. doi: $10.2337 / \mathrm{db} 16-0586$

144. Buckman LB, Thompson MM, Moreno HN, Ellacott KLJ. Regional astrogliosis in the mouse hypothalamus in response to obesity. J Comp Neurol. (2013) 521:1322-33. doi: 10.1002/cne.23233

145. Guyenet SJ, Nguyen HT, Hwang BH, Schwartz MW, Baskin DG, Thaler JP. High-fat diet feeding causes rapid, non-apoptotic cleavage of caspase-3 in astrocytes. Brain Res. (2013) 1512:97-105. doi: 10.1016/j.brainres.2013.03.033

146. Berkseth KE, Guyenet SJ, Melhorn SJ, Lee D, Thaler JP, Schur EA. Hypothalamic gliosis associated with high-fat diet feeding is reversible in mice: a combined immunohistochemical and magnetic resonance imaging study. Endocrinology. (2014) 155:2858-67. doi: 10.1210/en.2014-1121

147. Cheng KK, Lam KS, Wang B, Xu A. Signaling mechanisms underlying the insulin sensitizing effects of adiponectin. Best Pract Res Clin Endocrinol Metab. (2014) 28:3-13. doi: 10.1016/j.beem.2013.06.006

148. Yamauchi T, Kamon J, Waki H, Terauchi Y, Kubota N, Hara K, et al. The fat-derived hormone adiponectin reverses insulin resistance associated with both lipoatrophy and obesity. Nat Med. (2001) 7:941-6. doi: 10.1038/90984

149. Berg AH, Combs TP, Du X, Brownlee M, Scherer PE. The adipocyte-secreted protein Acrp30 enhances hepatic insulin action. Nat Med. (2001) 7:947-53. doi: $10.1038 / 90992$

150. Lin Z, Tian H, Lam KS, Lin S, Hoo RC, Konishi M, et al. Adiponectin mediates the metabolic effects of FGF21 on glucose homeostasis and insulin sensitivity in mice. Cell Metab. (2013) 17:779-89. doi: 10.1016/j.cmet.2013.04.005

151. Kharitonenkov A, Shiyanova TL, Koester A, Ford AM, Micanovic R, Galbreath EJ, et al. FGF-21 as a novel metabolic regulator. J Clin Invest. (2005) 115:1627-35. doi: 10.1172/JCI23606

152. Woo YC, Xu A, Wang Y, Lam KS. Fibroblast growth factor 21 as an emerging metabolic regulator: clinical perspectives. Clin Endocrinol. (2013) 78:489-96. doi: $10.1111 /$ cen. 12095

153. Deepa SS, Dong LQ. APPL1: role in adiponectin signaling and beyond. Am J Physiol Endocrinol Metab. (2009) 296:E22-36. doi: 10.1152/ajpendo.90731.2008

154. Ávalos Y, Hernández-Cáceres MP, Toledo L, Morselli E. Loss of autophagy in hypothalamic neurons may be involved in the pathogenesis of obesity. Autophagy. (2017) 12:295-312. doi: 10.1016/B978-0-12-812146-7. 00013-5

155. Meng Q, Cai D. Defective hypothalamic autophagy directs the central pathogenesis of obesity via the IkappaB kinase beta (IKKbeta)/NFkappaB pathway. J Biol Chem. (2011) 286:32324-32. doi: 10.1074/jbc.M111. 254417

156. Kaushik S, Rodriguez-Navarro JA, Arias E, Kiffin R, Sahu S, Schwartz GJ, et al. Autophagy in hypothalamic AgRP neurons regulates food intake and energy balance. Cell Metab. (2011) 14:173-83. doi: 10.1016/j.cmet.2011.06.008

157. Kaushik S, Arias E, Kwon H, Lopez NM, Athonvarangkul D, Sahu S, et al. Loss of autophagy in hypothalamic POMC neurons impairs lipolysis. EMBO Rep. (2012) 13:258-65. doi: 10.1038/embor.2011.260

158. Yerra VG, Kumar A. Adenosine-monophosphate-activated protein kinase abates hyperglycemia-induced neuronal injury in experimental models of diabetic neuropathy: effect on mitochondrial biogenesis, autophagy and neuroinflammation. Mol Neurobiol. (2017) 54:2301-12. doi: 10.1007/s12035-016-9824-3

Conflict of Interest Statement: The authors declare that the research was conducted in the absence of any commercial or financial relationships that could be construed as a potential conflict of interest.

Copyright (c) 2019 Benomar and Taouis. This is an open-access article distributed under the terms of the Creative Commons Attribution License (CC BY). The use, distribution or reproduction in other forums is permitted, provided the original author(s) and the copyright owner(s) are credited and that the original publication in this journal is cited, in accordance with accepted academic practice. No use, distribution or reproduction is permitted which does not comply with these terms. 